\title{
Okul Yöneticilerinin Yeşil Örgütsel Davranışlarını Belirlemeye Yönelik Bir Araştırma
}

\section{A Research on Determining Green Organizational Behaviors of School Administrators}

\author{
Ramazan Vedat Sönmez* \\ Dr. Öğr. Üyesi Şırnak Üniversitesi İktisadi ve İdari Bilimler Fakültesi I̦şletme Bölümü Şırnak/Türkiye. \\ ORCID: 0000-0001-8746-4657
}

\section{MAKALE BİLGİṠ \\ Makale Geçmişi: \\ Bașvuru tarihi: 03 Ekim 2019 \\ Düzeltme tarihi: 05 Mart 2020 \\ Kabul tarihi: 17 Mart 2020}

Anahtar Kelimeler:
Doğal Çevre
Çevre sorunları
Yeşil Örgütsel Davranış
Yönetim
Okul Yönetimi

\section{ARTICLE INFO}

\section{Article history:}

Received 03 October 2019

Received in revised form 05 March 2020

Accepted 17 March 2020

Keywords:
Natural Environment
Environmental problems
Green Organizational Behavior
Administration
School Management

Keywords:

Natural Environment

Green Organizational Behavior

School Management

\section{ÖZ}

Sanayi devrimi birlikte üretim süreçlerinde doğal kaynak kullanımında bir artış yaşanmaktadır. Bu artışa paralel olarak örgütler tarafından doğal çevreye salınan atıklarda önemli boyutlara ulaşmış bulunmaktadır. Doğal kaynaklar tüketildiği hızda kendini yenileyememektedir. Bu nedenle kaynakların bir nesilden diğerine aktarımı ve sürdürülebilirliği, çevre kirliliği son dönemlerde kamu ve özel sektör yöneticilerinin gündemini işgal etmektedir. Doğal kaynakların kullanımı ve çevreye verilen zarar örgütsel faaliyetler tarafından da etkilenmekte, örgütsel çatı altında çalışan tüm iş görenlerin dikkat etmeleri gereken bir husus olduğu ifade edilebilmektedir. Bu çalışmanın amacı; eğitim işletmelerinde faaliyette bulunan yöneticilerin yeşil örgütsel davranışlarını belirlemek, bir başka ifade ile okul yöneticilerinin çevresel duyarlılık, çevresel katılım, ekonomik duyarlılık, yeşil satın alma ve teknolojik duyarlılık düzeylerini ölçmek, bu konudaki tutumlarını belirlemek, ilgili literatüre katkı sunmak, konu ile ilgili yeni bir tartışma ortamı yaratabilmektir. Araştırma Şırnak ili, Cizre ilçesinde resmi okullarda görev yapan yöneticilere yönelik yapılmış olup veri toplama işleminde anket tekniği kullanılmıştır. Araştırma sonucunda; katılımcıların çevresel duyarlılık, çevresel katılım, ekonomik duyarlılık, yeşil satın alma ve teknolojik duyarlılık düzeylerinin oldukça yüksek seviyede olduğu bulunmuştur.

\section{A B S T R A C T}

There is an increase in the use of natural resources in the industrial revolution co-production processes. In parallel with this increase, it has reached important dimensions in the wastes released by the organizations to the natural environment. Natural resources cannot renew itself at the rate of consumption. Therefore, the transfer and sustainability of resources from one generation to the next, environmental pollution has recently occupied the agenda of public and private sector managers. The use of natural resources and damage to the environment also affect organizational activities, and it is stated all the employees in an organization are required to take this point into consideration. The purpose of this study; to determine the green organizational behavior of the administrators operating in educational enterprises, in other words, to measure the environmental sensitivity, environmental participation, economic sensitivity, green purchasing and technological sensitivity levels of school administrators, to determine their attitudes on this subject, to contribute to the relevant literature, creating a discussion environment. The research was carried out for administrators working in public schools in Cizre district of Şırnak province and survey technique was used in data collection. As a result of the research; It was found that the participants' environmental sensitivity, environmental participation, economic sensitivity, green purchasing and technological sensitivity levels were quite high.

\section{Giriș}

Üretim ve hizmet sektöründe büyük ölçekte üretim birimlerinin oluşması, makineleşmedeki artış ve teknolojideki ilerleme, örgütlerin verimlilik ve karlılıklarını artırırken, diğer taraftan kaynakların ve özellikle de doğal kaynakların kullanımını artırdığından, kaynakların sürdürülebilirliği ve bir takım çevre sorunlarını da beraberinde getirmiştir. Bu sonuca paralel olarak iklim değişiklikleri, kaynakların rezervleri ve doğal çevrenin

* Sorumlu yazar/Corresponding author

e-posta: rvsonmez@gmail.com

e-ISSN: 2149-4622. C 2013-2020 Muş Alparslan Üniversitesi. TÜBİTAK ULAKBİM DergiPark ev sahipliğinde. Her hakkı saklıdır. 
korunması kavramları da birçok araştırmacı için araştırma konusu olmuştur (Haden vd., 2009: 1041).

Günümüz yaşam koşullarında birey ve örgütlerin artan ve farklılaşan ihtiyaçlarının karşılanması, örgütlerin daha fazla kaynak ve zaman tüketimine yol açmaktadır. Artan bu ihtiyaçları karşılamak amacıyla kullanılan kaynaklardan en önemlisi de doğadan alınan ve belirli bir süreçten geçirildikten sonra toplumun hizmetine sunulan doğal kaynaklardır. Ancak kullanılan bu doğal kaynaklar sınırlı olduğundan veya tüketildiği hızda kendini yenilemediğinden gün geçtikçe azalmakta ve hatta yok olma tehlikesi ile karşı karşıya kalmaktadır. Diğer taraftan birey ve örgütlerin ihtiyaçlarını karşılamak amacıyla ürün üreten örgütler doğal kaynakları kullanmakla birlikte, kullanım sonrasında çevreye verdikleri zarar son dönemlerde tartışılan bir diğer önemli konuyu oluşturmaktadır. İnsan hayatı ve ekonomik faaliyetler için vazgeçilmez bir özellik taşıyan doğal çevrenin tehdit altında olması iktisadi faaliyetler açısından endişe verici bir boyut kazanmıştır (Bayraktutan ve İnmez, 306: 2017).

Örgütler doğadan aldıkları kaynakları bir süreçten geçirdikten sonra ürün olarak tüketicilerin hizmetine sunmaktadırlar. Kaynakların kullanım sonrası doğal çevreye verilen zararlar gün geçtikçe artmaktadır. Bununla birlikte kaynakların da sınırlı olması örgütleri doğal çevreyi koruma ve sürdürebilir bir çevrede faaliyetlerini devam ettirme konusunda duyarlı olmaya ve önlem almaya, bir başka ifade ile yeşil örgütsel davranışlara zorlamaktadır. Bu zorunluluk yasal düzenlemelerden, sosyal sorumluluktan, tüketici ve sivil toplum örgütlerinin baskılarından kaynaklanabilmektedir (Siegel, 2009: 14). Bu bask1 ve beklenti örgütleri ve iş görenleri faaliyetlerini icra ederken çevreye karşı en az zarar verme ve kaynakları kullanma noktasında dikkatli olmalarını gerektirmektedir. Örgütlerin üretim sürecinde kullandıkları kaynakların miktarı ve çevreye verdiği zarar, örgütsel çatı altında çalışan iş görenlerin davranışlarından etkilenebilmektedir. Çevrenin korunması konusunda bireylerin verdiği zarar önemli bir husus olmakla birlikte örgütlerin verdiği zarar daha büyük boyutlarda olabilmektedir (Karakuş ve Çelebi, 2018: 694)

Doğal çevrenin korunması ve sürdürebilirliğinin sağlanması açısından bakıldığında örgütlerin iş gören sayısı ve ülke geneline yayılma durumları önem kazanabilmektedir. Ülke geneli dikkate alındığında iş gören ve hizmet verilen kişi sayısı bakımından oldukça büyük örgütlerden biri de M.E.B.'na bağlı örgün eğitim kurumlarıdır. Kurum bünyesinde 66849 okul, 18108860 öğrenci ve 1077307 öğretmen bulunmaktadır. Bu açıdan bu okullarda görev yapan okul yöneticilerinin çevreye karşı olan duyarlılıkları araştırmaya değer bir konu olarak düşünülmektedir (Milli Eğitim Bakanlığgl).

Bu çalışmanın amacı; doğal ortamdan direkt olmasa bile, dolaylı bir şekilde kaynak alan ve kullanan, doğal çevrenin korunması konusunda bireyleri eğiten ve yol gösteren, toplumu bu konuda yönlendiren okul yöneticilerinin yeşil örgütsel davranışlarını belirlemek ve elde edilen veriler 1şı̆̆ında araştırmacılara, karar vericilere, kamu ve özel sektör yöneticilerine öneriler sunmaktır. Araştırma Şırnak ili Cizre ilçesinde resmi okullarda görev yapan yöneticileri kapsamaktadır. Araştırmanın veri toplama işleminde anket tekniği kullanılmıştır. Analizler SPSS 22.0 paket programı ile yapılmıştır.
Araştırma üç bölümden oluşmaktadır. Birinci bölümde kavramsal çerçeve sunulmuş, ikinci bölümde yapılan araştırma sonucu elde edilen veriler açıklanmış, son bölümde ise birtakım öneriler geliştirilmiştir.

\section{Kavramsal Çerçeve}

\section{1. Çevre Kavramı}

İnsanoğlunun yeryüzüne ayak basması ile birlikte çevre ile ilgili ilişkileri farklı dönemlerde farklı boyutlarda gerçekleşmiş, buna bağlı olarak çevre kavramı tarihsel süreç içinde değişik şekillerde tanımlanmıştır. Orhun yazıtlarında çevrenin etraf, Osmanlı döneminde ise muhit olarak ifade edildiği görülmüştür (Tekin, 1968: 249; Aydın, 2012:1089). Türk Dil Kurumu'na göre çevre; “hayatın gelişmesinde etkili olan doğal, toplumsal, kültürel dış faktörlerin bütünlüğü” olarak tanımlanmaktadır.

Bireyin dışındaki tüm varlıklardan oluşan, bireyin varoluşunu etkileyen, ekonomik, sosyal, kültürel ve fiziksel faktörlerin bileşiminden oluşan çevre yapay çevre olarak ifade edilmektedir (Dünya Sağlık Örgütü). Diğer taraftan bireylerin müdahalesi olmadan doğal yollarla, hava, toprak, su ve afetler gibi doğal unsurların etkisi ile oluşmuş doğal çevre bulunmaktadır. Bu iki çevre kavramının birleşimi bizi toplam çevre kavramına ulaştırmaktadır. Yapay çevre ve doğal çevre sürekli olarak birbirleri ile etkileşim halinde bulunmaktadır. Örgütlerin bir süreçten sonra ürettikleri ürünler yapay çevre ürünleri olup, bu ürünlerin üretimi sırasında doğal çevre birtakım zararlar görebilmektedir (Tiraş, 2002: 65).

Son dönemlerde insanoğlunun çevreye karşı olumsuz tutumu ve küresel anlamda yaşanan doğal tahribatlar, çevreye karşı olan duyarlılığın artması ve konu ile ilgili yapılan araştırmalardaki artış çevre tanımının gözden geçirilmesi ve revize edilmesi ihtiyacını ortaya çıkarmıştır. $\mathrm{Bu}$ açıdan incelendiğinde çevre; bireyin faaliyetleri üstünde uzun veya kısa vadede dolaylı veya direkt olarak etkide bulunabilecek biyolojik, kimyasal ve fiziksel etmenlerin belirli bir zaman sürecindeki toplamı olarak açıklanmaktadır (Kahraman ve Türkay, 2014: 21). Ekoloji, yaşam çevresi gibi kavramlarla da ifade edilen çevre kavramı kendi bünyesinde canlı ve cansız olmak üzere iki unsuru barındırmakta olup, hava, toprak, su, ekosistem ve iklim cansız unsurları, insanlar, mikroorganizmalar, hayvanlar ve bitki örtüsü ise canlı unsurları oluşturmaktadır (Torunoğlu, Koparel, Tezcan ve Göncü, 2012:5).

Tarihsel açıdan çevre sorunları her dönemde insanoğlunun karşısına çıkmasına karşılık, bu sorunların ekolojiye zarar vermesi ve doğal kaynaklara yönelik bir tehdit halini alması son yüzyılda karşılaşılan bir olgudur. Sanayi Devrimi ve buna dayalı olarak ortaya çıkan zihinsel dönüşüm doğal çevrenin tahribatında önemli bir eşiktir. Teknolojinin gelişmesi, insanoğlunun daha lüks ve konforlu bir yaşam isteği, örgütlerin büyüme hırsı, gelecek dönemlerde ekolojik çevreyi ve dengeyi bozacağı ve hatta ortadan kaldırabileceği dikkate alınmamıştır (Görmez, 1997: 1). Yaşadığımız yüzyılda kırsal kesimlerden şehir merkezlerine doğru yaşanan göç hareketleri sonucu oluşan büyük yerleşim yerleri ve artan nüfus, oluşan hava kirliliği, iklim değişiklikleri, sanayileşmenin atıkları, deterjanlar, tarımda kullanılan kimyasal gübreler ve mücadele ilaçları ile ortaya 
çıkan su kaynaklarının kirliliği süreç içinde büyük boyutlara ulaşmıştır (Keleş ve Hamamc1, 2005: 115).

İçinde yaşadığımız yüzyılda örgütler ve bireyler doğal kaynakları kullanarak ihtiyaçları karşılamakta, ancak gelecek yüzyıllarda yaşayacak nesillerin ihtiyaç duyacakları kaynakları da yok edebilmektedir. Yaşadı̆̆ımız doğal felaketler ve çevre sorunları sonucunda, tarım alanları azalmakta, doğal afetler artmakta, ormanlık alanlar hızla tahrip edilmekte, su dünyasında yaşayan canlılar azalmakta, artan nüfusla birlikte yoksulluk artmakta, bulaşıcı hastalıklar insanlığı tehdit eder hale gelmektedir (Hart, 2008: 112).

Kamu ve özel sektörde faaliyet gösteren örgütlerin artan nüfusun ihtiyaçlarını karşılama ve aşırı kar elde etme isteği, doğal kaynakların kullanımındaki dengesizlik ve sorumsuzluğun çevreye verdiği zarar ve bunun sonucunda oluşan tahribat, insanlığın geleceğinin tehdit altında olması başta tüketiciler olmak üzere birçok kesimin tepkisini çekmiş, çevre bilincinin artmasıyla çevreye zarar veren ve doğayı tahrip eden örgütler, tüketici ve sivil toplum örgütlerinin çeşitli tepkilerine maruz kalmış ve yasal olarak birtakım müeyyidelerle karşı karşıya kalmışlardır (Koçarslan, 2015: 98) Diğer taraftan bilinçli tüketiciler de satın aldıkları ürünlerin çevreye vermiş olduğu zararı dikkate alarak, tüketim harcamalarına yön verebilmekte, örgütlerin bu konuda daha duyarlı olmalarını beklemektedir. $\mathrm{Bu}$ şartlar örgütleri çevreye karşı daha duyarlı olmaya, üretim ve hizmet süreçlerinde, ürünlerinde, davranışlarında ve pazarlama yöntemlerinde çevreci davranış olarak da bilinen yeşil davranış sergilemeye yönlendirmektedir. Günümüz üretim ve hizmet sektöründe örgütler doğal çevreye karşı olan duyarlılı̆̆ bir maliyet kavramından çok önemli bir rekabet aracı olarak görmeleri gerekmektedir (Lee vd., 2006: 292).

\subsection{Yeşil Örgütsel Davranış}

1960 ve 1970'li yıllardan itibaren doğal çevre ile ilgili konulara olan ilgi artmış, çevresel konular işletme yöneticileri ve siyasi temsilcilerin gündemlerinde önemli bir yer tutmuştur. Yaşadığımız yüzyılda doğal kaynakların hızla tüketilmesi ve çevre sorunları nedeni ile ekonomi dünyasında faaliyette bulunan örgütler sadece karlılık ve rekabet açısından değil, aynı zamanda doğal çevreye karşı tutumlarında da başarılı olmak durumunda kalmışlardır (Straughan ve Roberts, 1999; 559).

Kamu yöneticileri, tüketiciler ve baskı grupları örgütleri ürettikleri ürünün kalitesi ve fiyatı ile birlikte doğal çevreyi ne kadar korudukları veya ne kadar zarar verdikleri konusunda değerlendirmektedirler. Örgütler karlılıklarını sürdürmek ve sürdürülebilir bir çevrede faaliyetlerine devam etmek için tüketici ve baskı gruplarının çevre konusundaki beklentilerini karşılamak durumundadırlar. $\mathrm{Bu}$ süreç örgütleri doğal çevreye karşı duyarlı olmaya, doğal kaynakları kullanırken dikkatli olmaya bir başka ifade ile yeşil örgütsel davranış göstermeye zorlamaktadır.

1990'lı y1llarda ortaya çıkan ve 2000'li yıllarda popüler olan, diğer alanlarda olduğu gibi yönetim alanında gündem oluşturan bir kavram olarak yeşil örgütsel davranış; örgütsel çatı altında çevresel sürdürülebilirliği önemseyen ve buna katkı sunan, çevreye yönelik zararları en aza indiren davranış ve eylemler olarak ifade edilebilir (Ones ve Dilchert"e (2012: 456).
Yeşil örgütsel davranış kavramı yeni bir kavram olduğundan, ilgili alan yazın incelendiğinde bu kavramın farklı şekillerde ifade edildiği görülmektedir. Molina ve arkadaşları (2009:1081) örgütlerdeki yeşil örgütsel davranışları yeşil yönetim olarak açıklamışlardır. Buna göre yeşil yönetim; süreçlerin geliştirilmesinde ve ürünlerin üretilmesinde çevrenin de dikkate alınarak ortaya çıkabilecek zararların ortadan kaldırılması veya en aza indirilmesi amacıyla, yapı ve yönetsel uygulamaların buna göre tasarlanması olarak ifade etmektedirler. Stern (2000: 408) yaptığı çalışmada yeşil örgütsel davranış1, bireylerin doğal çevre üzerindeki faaliyetlerinin olumsuz sonuçlarını azaltmaya yönelik davranışlar olarak açıklamaktadır. Bir diğer tanımlama da kavram, doğal çevrenin sürdürülebilirliğine katkıda bulunan, enerji tüketimini azaltan ve kaynak kullanımında israftan kaçınan bireysel davranışlar olarak ifade edilmektedir (Mesmer-Magnus vd.2012: 159).

Yeşil örgütsel davranış veya yeşil yönetim kavramının ortaya çıkmasına kaynaklık teşkil eden husus sürdürebilir çevre anlayışıdır. Örgütler açısından sürdürülebilir çevreden kasıt, kaynakların elde edilmesi ve kullanılmasında bir taraftan bugünün ihtiyaçlarının dikkate alınmas1, diğer taraftan gelecekte örgütlerin ürün üretiminde ihtiyaç duyabileceği kaynakların sağlanması amacıyla çevresel duyarlılığı ifade etmektedir. Bir başka ifade ile örgütlerin sürdürülebilir çevrede kullandığı teknoloji ve gerçekleştirdikleri faaliyetler sonucu kaynakların tasarruflu ve verimli kullanımını, oluşan atıkların doğal çevreye verdiği zararları yok etmeyi veya en aza indirmeyi hedefleyen, bu yolla doğal çevrenin dengesini bozmadan geleceğe taşımayı ifade etmektedir (Simula vd., 2009: 331).

Tablo 1: Klasik Yönetim ile Yeşil Yönetim Karşılaştırılması

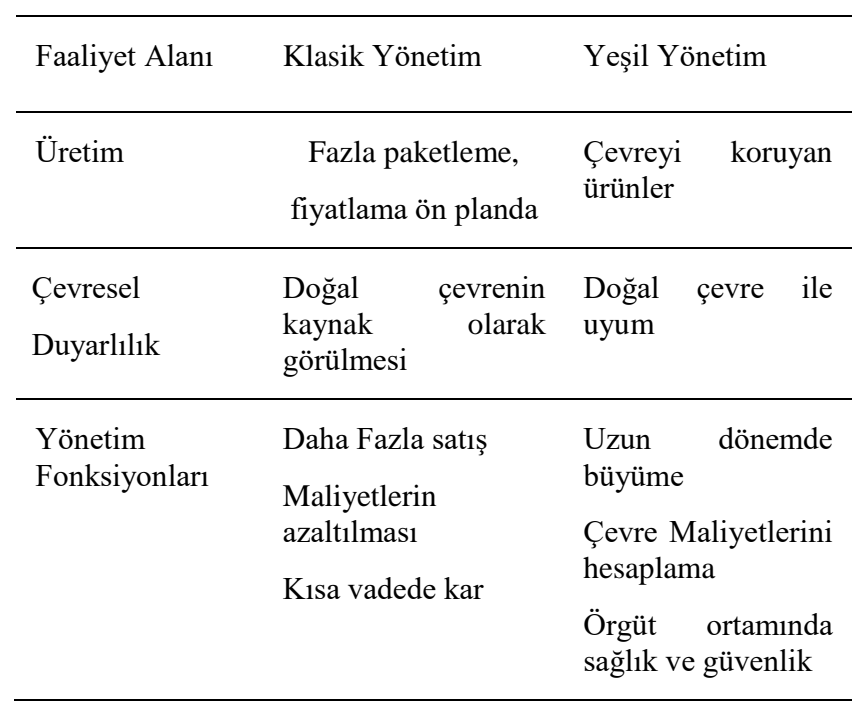

Kaynak: Shrivastava, 1995: 130

Araştırmada ele alınan yeşil örgütsel davranış kavramı; çevresel duyarlılık, çevresel katılım, ekonomik duyarlılık, yeşil satın alma ve teknolojik duyarlılık olmak üzere beş alt boyutu kapsamaktadır. Bu alt boyutların açıklamaları kısaca aşağıda yapılmıştır (Erbaşı, 2018: 589):

-Çevresel duyarlılık; iş yerinde kullanılan enerjinin gereksiz yere kullanılmasını engellemeyi, enerji kaynaklarının fazla kullanılmasına yol açan malzemelerin değiştirilmesi veya kullanımdan çıkarılmasını, geri 
dönüşüme kazandırılma imkânı olan malzemelerin muhafaza edilmesi ve ilgili yerlere gönderilmesini, atık malzemelerin kullanılması ve değerlendirilmesini, su ve elektrik kaynaklarının tasarruflu kullanımını ifade etmektedir.

- Çevresel Katılım; doğal çevreye duyarlı olan örgütlerin tercih edilmesi, örgüt çatısı altında çalışan iş görenlerin doğal çevreye zarar verecek davranışlarda bulunulmasının engellenmeye çalışıldı ğı, yöneticilere, ortaklara ve diğer paydaşlara çevrenin korunması konusunda önerilerin sunulduğu, çevrenin korunmasına yönelik faaliyetlere katılımın sağlandığı, örgüt yönetimi ve kamu yönetimi tarafindan konulan yasal uygulamalara uymayı ifade etmektedir.

-Ekonomik Duyarlılık; iş ortamında gün 1şı̆̆ından yararlanmayı, eldeki kaynaklardan tam kapasite ile faydalanmayı, kullanılan enerji kaynakları ile ilgili ortaya çıkabilecek kayıpların en aza indirilmesi için gerekli tedbirlerin alınması, ulaşım sürecinde toplu taşıma araçlarının tercih edilmesini ifade etmektedir.

- Teknolojik Duyarlılık; örgütte kullanılan teknolojik araçların tasarruflu kullanılması, zorunlu olmadıkça bazı araçların kullanılmamasını, enerjide tasarrufun sağlanması, tekrar tekrar kullanılabilecek araçların tercih edilmesini ifade eder.

- Yeşil Satın alma; örgütün ihtiyaç duyduğu ürünleri, çevre dostu olanlardan tercih etme, iş görenleri çevreye karşı duyarlı olmaya yönlendirme, satın alınan ürünlerin kullanma tarihini kontrol etme, tek kullanımlık ürünlerden çok tekrar tekrar kullanılabilecek ürünleri kullanmayı ifade etmektedir (Erbaş1, 2018: 589).

\subsection{Yeşil Örgütsel Davranışın Nedenleri}

\subsubsection{Tüketici Basklsı}

Sanayi devrimi ile birlikte kitlesel üretime geçiş, örgütlerin aşırı kar hırsı, doğadan alınan kaynakların hiç tükenmeyecek gibi kullanımı, nüfus göçü, kentleşme ve teknolojik gelişmeler doğal çevrenin tahribatını hızlandırmış, özellikle 1970'li yıllardan itibaren insanoğlunun çevrenin korunması ve sürdürülebilirliği gibi yeni bir sorunla karşılaşmasına yol açmıştır. Bireyin doğal bir çevrede yaşama zorunluluğu ve ihtiyacı, insanoğlu ve doğal çevre başlıkları araştırmacıların birlikte araştırdığı konular arasına girmiştir. Doğal çevre de oluşan tahribat ve tükeniş insanoğlunda birtakım kaygılara ve korkuya sebep olmuştur. Bu kaygı ve korku tüketicilere de yansımakta, ürün satın alan tüketiciler doğal çevreyi dikkate alan ve en az zararı veren ürünleri tercih edebilmektedir. Bazı ülkelerde tüketiciler ürün veya ambalajın üstünde çevreyi koruduğuna dair işaretler bulunmayan ürünleri tercih etmeyerek örgütleri yeşil örgütsel davranışa yönlendirebilmektedirler (Gökbunar, 1995: 5). Tüketicilerin çevreyi dikkate alan satın alma davranışı örgütleri kaynak kullanımı ve çevreyi koruma konusunda duyarlı olmaya ve korumaya zorlamaktadır. Bu sürece paralel olarak örgütler üretim süreçlerinde ve kaynak kullanımında tüketicilerin bu duyarlılıklarını göz önünde bulundurarak yeşil ürünler üretmek ve kaynak kullanımı sonucunda çevreye verdikleri zararı minimize etmek için çaba göstermektedirler. Örgütler sadece üretim sürecinde değil aynı zamanda pazarlama yöntemlerinde ve muhasebe düzenlerinde de yeşil örgütsel davranış sergilemeye doğru yönelmektedir. Tüketicilerin çevre konusundaki duyarlılıklarını dikkate alan ve bu süreçleri başaran ve uygulayan örgütlerin, özellikle yeşil ürün konusunda duyarlı olan tüketiciler nezdinde olumlu bir imaja sahip olabilecekleri ifade edilebilmektedir. (Varinli, 2000:15). Tüketicilerin çevre konusundaki bu duyarlılıkları, örgütlerin üretim, pazarlama ve muhasebe başta olmak üzere diğer süreçlerinde çevreyi dikkate almaları ve kaynak kullanımı konusunda verimliliği, tasarrufu ve sürdürülebilirliğe özen göstermeleri yönünde bask1 oluşturabilmektedir.

Tüketicilerin piyasada görmek istedikleri ve satın aldıkları yeşil ürün özellikleri;

*Doğal çevreyi kirletmeyen veya zararlı olmayan,

*İçerdiği kimyasallar itibarıyla zehirli olmayan,

*İçerik olarak doğal olan,

*Yeniden kullanma özelliğine sahip ve geri dönüştürülebilen,

*Çevre ile dost olan, yeniden kullanım özelliğine sahip,

*Orijinal olarak yetiştirilen,

*İçerdiği kimyasallar açısından onaylanan ürünlerdir (Mishra ve Sharma, 2010: 10).

Tüketici ve örgütlerin göstermiş olduğu tepkiye rağmen yeşil ürün tüketiminin halen istenilen seviyede olduğu ifade edilemez. Araştırmalar yeşil ürün tüketiminin toplam tüketim içindeki payının \%4 civarında olduğunu göstermektedir (Ritter vd. 2015: 508).

\subsubsection{Cevre Yönetmelikleri}

Birey ve örgütlerin doğal kaynakları kullanımı ve sonrasında oluşan çevre sorunları ile ilgili kamu yönetimleri de harekete geçmiş gerek ülkemizde gerekse uluslararası alanda çeşitli yasal düzenlemeler yapılmıştır. Türkiye'de son yıllarda oluşturulan, sanayi ve ekonomi dünyası açısından da önem taşıyan çevre mevzuatı yedi temel yönetmelikten oluşmaktadır (Sürdürülebilir Kalkınma Dünya Zirvesi Türkiye Ulusal Raporu, 2002: 117).

- Tehlikeli Atık Kontrol Yönetmeliği; bu yönetmeliğin temel amacı, tehlike arz eden atıkların, üretim aşamasından nihai bertarafina kadar; insan ve çevre sağlığına zarar verecek şekilde doğrudan veya dolaylı bir şekilde alıcı ortama aktarılmasının önlenmesine, yönetiminde gerekli teknik ve idari standartların sağlanmasına, yeterli bertaraf tesisi kurulması ve bu tesislerin çevresel bakımdan sağlıklı bir şekilde kontrolüne, çevreyle uyumlu yönetiminin sağlanmasına yönelik prensip, politika ve programların belirlenmesi için hukuki ve teknik esasları kapsar.

- Çevresel Etki Değerlendirme (ÇED) Yönetmeliği; bu yönetmeliğin amacı, çevresel etki değerlendirmesi (ÇED) sürecinde uyulacak idari ve teknik usul ve esasları düzenlemektir.

- Su Kirliliği Kontrol Yönetmeliği; bu yönetmeliğin amac1, ülkenin yeraltı ve yerüstü su kaynakları potansiyelinin korunması ve en iyi bir biçimde kullanımının sağlanması için, su kirlenmesinin önlenmesini, sürdürülebilir kalkınma hedefleriyle uyumlu bir şekilde gerçekleştirmek üzere gerekli olan hukuki ve teknik esasları belirlemektir. 
- Tıbbi Attklar Kontrol Yönetmeliği; bu yönetmeliğin amacı, tıbbi atıkların oluşumundan bertarafina kadar; çevreye ve insan sağlı̆̆ına zarar verecek şekilde doğrudan veya dolaylı bir biçimde alıcı ortama verilmesinin önlenmesine, çevreye ve insan sağllğına zarar vermeden kaynağında ayrı olarak toplanması, sağlık kuruluşu içinde taşınması, geçici depolanması, tıbbi atık işleme tesisine taşınması ve bertaraf edilmesine, yönelik prensip, politika ve programlar ile hukuki, idari ve teknik esasların belirlenerek uygulanmasına ilişkin usul ve esasları düzenlemektir.

- Katı Attklar Kontrol Yönetmeliği; bu yönetmeliğin amac1; her türlü atık ve artı̆̆ın çevreye zarar verecek şekilde, doğrudan veya dolaylı bir biçimde alıcı ortama verilmesi, depolanması, taşınması, uzaklaştııılması ve benzeri faaliyetlerin yasaklanması, çevreyi olumsuz yönde etkileyebilecek olan tüketim maddelerinin idaresini belli bir disiplin altına alarak, havada, suda ve toprakta kalıcı etki gösteren kirleticilerin hayvan ve bitki nesillerini, doğal zenginlikleri ve ekolojik dengeyi bozmasının önlenmesi ile buna yönelik prensip, politika ve programların belirlenmesi, uygulanması ve geliştirilmesidir.

- Hava Kalitesi Kontrol Yönetmeliği; bu yönetmeliğin amacı; hava kirliliğinin çevre ve insan sağlığı üzerindeki zararlı etkilerini önlemek veya azaltmak için hava kalitesi hedeflerini tanımlamak ve oluşturmak, tanımlanmış metotları ve kriterleri esas alarak hava kalitesini değerlendirmek, hava kalitesinin iyi olduğu yerlerde mevcut durumu korumak ve diğer durumlarda iyileştirmek, hava kalitesi ile ilgili yeterli bilgi toplamak ve uyarı eşikleri aracılığı ile halkın bilgilendirilmesini sağlamaktır (Sürdürülebilir Kalkınma Dünya zirvesi Türkiye ulusal raporu)

\subsubsection{Sosyal Sorumluluk}

İşletmeleri yeşil örgütsel davranışa yönlendiren ve zorlayan bir diğer etken, işletmelerin sosyal sorumluluklarıdır. İşletmeler açısından sosyal sorumluluk, üretim sürecinden tüketim sürecine kadar yapılan faaliyetlerin, toplum ve doğal çevreye karşı zararlı etkisinden dolayı işletmeyi sınırlandıran, toplumsal refahı artırmaya yönelik uygulama ve stratejilerin benimsenmesini ifade etmektedir (Y1lmaz, 2006: 68). Bir başka ifade ile işletmelerin topluma karşı kendini sorumlu hissetme davranışıdır.

İşletmeler faaliyette bulundukları toplumun ihtiyaçlarını karşılamakla birlikte, bir diğer görevi sosyal sorumluluklarını yerine getirmeleridir. İşletmeler açısından çevre ve doğal kaynaklar sadece bir faaliyet alanı değil aynı zamanda korumaları ve sürdürmeleri gereken bir alandır. İşletmeler bir taraftan ekonomik olarak amaçlarına ulaşmaya çalışırlarken diğer taraftan çevreye karşıda sorumlulukların yerine getirmek durumundadırlar. $\mathrm{Bu}$ nedenle çevreden aldıkları kaynakları etkin ve verimli bir şekilde kullanmak, kullanılan kaynaklar sonucu oluşan atıkları minimize etmek veya oluşan bu atıkları çevreye en az zarar verecek şekilde doğaya bırakmak durumundadırlar. Bilgiye ulaşmanın kolay olduğu, iletişimin son derece hızlandığı günümüz şartlarında tüketiciler ürünlerin fiyat ve kaliteleri ile birlikte işletmelerin kullandıkları kaynakları ve bu kaynakların kullanımı sonucu oluşan çevre sorunlarını da dikkate alabilmekte, bu düşünce satın alma davranışlarına yansıyabilmektedir. Dolayısıyla örgütler tüketicilerin bu hassasiyetlerini dinleme, ürünlerin üretiminde, pazarlanmasında ve satışında sözkonusu hususlara dikkat etmeleri gerekmektedir.

\section{Araştırmanın Yöntemi}

Araştırmada veri toplama işleminde anket tekniği kullanılmıştır. Kullanılan anket iki bölümden oluşmakta olup, birinci bölümde katılımcıların doğal çevreye karşı tutumlarını ölçmeye yönelik, çevresel katılım, çevresel duyarlılık, ekonomik duyarlılık, yeşil satın alma ve teknolojik duyarlılık olmak üzere toplam beş alt boyutu kapsayan ifadeler yer almaktadır. Anketin ikinci bölümünde ise katılımcıların demografik özelliklerini belirlemeye yönelik ifadeler yer almaktadır. Söz konusu anket Erbaşı tarafindan geliştirilmiş" Yeşil Örgütsel Davranış: Özgün Bir Ölçek Geliştirme" başlıklı çalışmadan alınmıştır (Erbaşı, 2019: 1-23).

\subsection{Araştırmanın Amacı}

Yukarıda belirtilen yönetmelikteki maddelerden biri olan kaynakların verimli kullanılması ve çevreyle bütünleşmesi, yöneticilerin kendi uhdelerine verilen kaynakları etkin, verimli ve doğal çevreye zarar vermeden kullanmalarını zorunlu kılmaktadır.

Her ne kadar okul yöneticileri kullandıkları kaynakları direkt olarak doğadan almasa bile dolaylı olarak bu kaynakları kullanmaktadır. Örgütün ihtiyaç duyduğu ürünleri, çevre dostu olanlardan tercih etme, iş görenleri çevreye karşı duyarlı olmaya yönlendirme, örgütte kullanılan teknolojik araçların tasarruflu kullanılmasını sağlama, tekrar tekrar kullanılabilecek araçların tercih edilmesi, iş ortamında gün ışığından yararlanmayı, eldeki kaynaklardan tam kapasite ile yararlanmayı, kullanılan enerji kaynakları ile ilgili ortaya çıkabilecek kayıpların en aza indirilmesi için gerekli tedbirlerin alınması, örgüt çatısı altında çalışan iş görenlerin doğal çevreye zarar verecek davranışlarda bulunulmasının engellenmeye çalışılması, yöneticilere, ortaklara ve diğer paydaşlara çevrenin korunmas1 konusunda önerilerin yapılması, çevrenin korunmasına yönelik faaliyetlere katılımın sağlanması, örgüt yönetimi ve kamu yönetimi tarafından konulan yasal uygulamalara uyma, iş yerinde kullanılan enerjinin gereksiz yere kullanılmasını engelleme, enerji kaynaklarının fazla kullanılmasına yol açan malzemelerin değiştirilmesi veya kullanımdan çıkarılması, geri dönüşüme kazandırılma imkânı olan malzemelerin muhafaza edilmesi ve ilgili yerlere gönderilmesi, atık malzemelerin kullanılması ve değerlendirilmesi, su ve elektrik kaynaklarının tasarruflu kullanımı açısında okul yöneticilerinin tutum ve yaklaşımı doğal çevrenin korunması ve kaynakların etkin ve verimli kullanılması açısından önem kazanmaktadır (Erbaşı, 2019;1-23).

$\mathrm{Bu}$ çalışmamızın amacı; eğitim işletmelerinde faaliyette bulunan yöneticilerin yeșil örgütsel davranıșlarını belirlemek, bir başka ifade ile okul yöneticilerinin çevresel duyarlılık, çevresel katılım, ekonomik duyarlılık, yeşil satın alma ve teknolojik duyarlılık düzeylerini ölçmek, bu konudaki tutumlarını belirlemek, ilgili literatüre katkı sunmak, konu ile ilgili yeni bir tartışma ortamı yaratabilmektir.

\subsection{Araştırmanın Evreni ve Örneklem}


Okul yöneticiliği; eğitim alanında belirlenen hedefleri gerçekleştirmek amacıyla sahip olunan tüm maddi ve manevi kaynakların etkin ve verimli bir şekilde kullanılmasını, hedeflerle ilgili planlama ve koordinasyonun yapıldığı bir süreci ifade etmektedir (Ünal ve Ada, 2001: 75). Eğitim alanında belirlenen hedefler okul yöneticileri tarafından gerçekleştirilmektedir. Okul yöneticilerinin başarısı ile eğitim kurumlarının başarısı yakından ilişkilidir. $\mathrm{Bu}$ nedenle eğitim kurumlarının hedeflerini gerçekleștiren yöneticilerin birtakım niteliklere sahip olması gerekmektedir. $\mathrm{Bu}$ nitelikler; birey odaklı olma, eleştirel bir bakış açısına sahip olma, tüm paydaşlara karşı tarafsız olma, hedefleri belirleme, uygun bir örgüt iklimi oluşturabilme, iş görenlerini değerlendirebilmedir (Eriçok, 2014: 72-73).

Millî Eğitim Bakanlığı Ortaöğretim Kurumları Yönetmeliğine göre; okul yöneticisi, M.E.B.'e bağlı eğitim kurumlarında müdür yardımcısı, müdür başyardımcısı, kampüs müdürü ve müdür görevlerinde bulunanları ifade etmektedir. Söz konusu yönetmelik okul yöneticilerine bir takım görev ve sorumluluklar yüklemektedir. Buna göre okul yöneticilerinin eğitim-öğretim işlerini planlamak, öğrencilere, velilere ve öğretmenlere kılavuzluk yapmak, kaynakların verimli kullanılmasına çalışmak, çevreyle iletişim kurup bütünleşmek, örgütsel bir kültür oluşturmak, eğitimin başarılı bir şekilde gerçekleşmesi için uygun ortam hazırlamak, yenilikleri takip etmek ve okulu geliştirme gibi sorumlulukları bulunmaktadır (Millî Eğitim Bakanlığı).

Araştırmanın evrenini Şırnak ili Cizre İlçesinde M.E.B.'e bağlı resmi okullarda görev yapan okul yöneticileri oluşturmaktadır. $\mathrm{Bu}$ kapsamda İlçe milli eğitim müdürlüğünden alınan bilgilere göre İlçede toplam 50 okulda 106 yönetici görev yaptığı bilgisi alınmıștır. Görev yapan yöneticilerin tamamına anket formu dağıtılmış ancak 103 yönetici geri dönüş (\%97) sağlamıştır. Değerlendirme 103 anket verisine göre yapılmıştır. $\mathrm{Bu}$ bağlamda 103 örneklem sayısı ana kütleyi temsil edebilecek yeterliliktedir.

\subsection{Araştırmanın Hipotezleri}

Yönetim ve organizasyon alanında çevrenin korunmasını sağlayan ve sürdürülebilirliği teşvik eden organizasyonlar ile bu organizasyonlara uygun davranışların sergilenmesi yeşil örgütsel davranış olarak ifade edilmektedir (Kim vd., 2014:3). İlgili alan yazında yeşil örgütsel davranış veya yeşil iş gören davranışı olarak ifade edilen kavram genellikle gönüllülük esasına dayanmaktadır. Kavram bu yönü ile örgütsel vatandaşlık kavramına benzemektedir (Yiğit, 2017; 2). Yeşil örgütsel davranışların zorunluluktan çok gönüllülük esasına dayanması işgörenlerin kavrama karşı olan tutumlarında farklılaşmalar görülebilmektedir. $\mathrm{Bu}$ nedenle çalışmada, işgörenlerin yaş, cinsiyet, çalışma yılları, işyerindeki konumu ve görev yaptıkları kurumun özelliğine göre yeşil örgütsel davranış sergilemede farklılık gösterip göstermediği tespit edilmek istenmiştir. Bununla birlikte Erbaşı'nın (2019;1-23) yaptığı çalışmada ortaya koyduğu örgütsel davranışın beş alt boyutun iş görenlerin davranışlarını etkilediği varsayımı ile hipotezler geliştirilmiştir.

$\mathrm{H}_{1}$ : Katılımcıların çevresel duyarlılık düzeyleri ile çevresel katılım düzeyleri arasında pozitif yönlü ve anlamlı bir ilişki vardır.
$\mathrm{H}_{2}$ : Katılımcıların çevresel duyarlılık düzeyleri ile ekonomik duyarlılık düzeyleri arasında pozitif yönlü ve anlamlı bir ilişski vardır.

$\mathrm{H}_{3}$ : Katılımcıların çevresel duyarlılık düzeyleri ile yeşil satın alma düzeyleri arasında pozitif yönlü ve anlamlı ilişki vardir.

$\mathrm{H}_{4}$ : Katılımcıların çevresel duyarlılık ve teknolojik duyarlılık düzeyleri arasında pozitif yönlü ve anlamlı bir ilişki vardır.

$\mathrm{H}_{5}$ : Katılımcıların çevresel katılım ve ekonomik duyarlılık düzeyleri arasında pozitif yönlü ve anlamlı bir ilişki vardır.

$\mathrm{H}_{6}$ : Katılımcıların çevresel katılım ve yeşil satın alma düzeyleri arasında pozitif yönlü ve anlamlı bir ilişki vardır.

$\mathrm{H}_{7}$ : Katılımcıların çevresel katılım ve teknolojik duyarlılık düzeyleri arasında pozitif yönlü ve anlamlı bir ilişki vardır.

\section{3. İstatistiksel Analiz Yöntemleri}

Verilerin analizi konusunda; tanımlayıcı istatistikler frekans, yüzde, ortalama, standart sapma değerleri ile sunulmuştur. Çalışmada iki evre gruplarda farklılığının test edilmesi için tek örneklem t testi analizi uygulanmıştır. Üç evre grubun karşılaştırılmasında varyans analizi (ANOVA) testi kullanılmıştır. Değişkenler arasındaki ilişkinin tespit edilmesi amacı ile korelasyon analizleri uygulanmıştır. Çalışmada 0,05 'den küçük p değerleri istatistiksel olarak anlamlı kabul edilmiştir. Analizler SPSS (Statistical Package for the Social Sciences) 22.0 paket programı ile yapılmıştır.

\subsection{Güvenilirlik ve Geçerlilik Testleri}

Okul yöneticilerin yeşil örgütsel davranış düzeylerinin ölçülmesi ile ilgili ifadelerden oluşan ölçeğin güvenilirliğinin Cronbach. Alpha katsayısı 0,92 olduğu tespit edilmiştir. Katsayı ölçeğin oldukça yeterli sayılacak kadar güvenilir olduğunu göstermektedir. Güvenilirlik analizinin ardından yapı geçerliliğinin test edilmesi amacı ile ölçeğe açımlayıcı faktör analizi uygulaması yapılmıştır.

Tablo 1: Güvenilirlik ve Geçerlilik analizleri

\begin{tabular}{|c|c|c|c|c|c|c|}
\hline 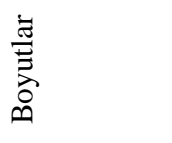 & $\mathrm{X}$ & S.S & 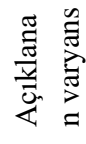 & 兽 & $\stackrel{:=}{:}$ & $\sum_{\unrhd}^{\varrho}$ \\
\hline $\begin{array}{l}\text { Çevresel } \\
\text { Duyarlılık }\end{array}$ & 4.33 & 0.59 & $17 \%$ & 0.81 & & \\
\hline $\begin{array}{l}\text { Çevresel } \\
\text { Katılım }\end{array}$ & 4.06 & 0.58 & $18 \%$ & 0.83 & & \\
\hline $\begin{array}{l}\text { EkonomikD } \\
\text { uyarlılık }\end{array}$ & 4.05 & 0.63 & $17 \%$ & 0.81 & $\begin{array}{l}0.92 \\
0.90\end{array}$ & \\
\hline $\begin{array}{l}\text { Yeşil Satın } \\
\text { alma }\end{array}$ & 4.02 & 0.60 & $16 \%$ & 0.82 & & \\
\hline $\begin{array}{l}\text { Teknolojik } \\
\text { Duyarlılık }\end{array}$ & 4.14 & 0.48 & $16 \%$ & 0.82 & & \\
\hline
\end{tabular}

Yeşil örgütsel davranış ölçeğinde faktör analizi sonucunda beş adet alt boyut tespit edilmiştir. Bu boyutlar çevresel duyarlılık, çevresel katılım, ekonomik duyarlılık, yeşil satın alma ve teknolojik duyarlılık boyutu olarak adlandırılmıştır. Faktör analizinde hesaplanan KMO örneklem yeterlilik katsayısı 0,90 olarak tespit edilmiştir. Katsayı yapılan 103 adet anketin faktör yapısını orta koymak için yeterli 
olacağının göstergesidir. Ayrıca faktör yapılarının anlamlılığının test edildiği Bartlet küresellik testi sonucuna göre $(p=0,001, p<0,05)$ elde edilen boyutlar yapısal açıdan geçerlidir. Faktör analizi sonucunda elde edilen bulgular, ölçeğin orijinalini (581-590; Erbaş1, 2019: 1-23) desteklemiş ve yeşil örgütsel davranış ölçeği maddelerinden herhangi birinin çıkarılmasına gerek kalmamıştır.

Çevresel duyarlılık boyutu açıklanan varyansın \%17'sini açıkladığı ve iç tutarlılık düzeyinin 0,81 düzeyinde olduğu, çevresel katılım boyutu açıklanan varyansın \%18'ini açıkladığı ve iç tutarlılık düzeyinin 0,83 düzeyinde olduğu, ekonomik duyarlılık boyutu açıklanan varyansın \%17'sini açıkladığı ve iç tutarlılık düzeyinin 0,81 düzeyinde olduğu, yeşil satın alma boyutu açıklanan varyansın \%16'sını açıkladığı ve iç tutarlılık düzeyinin 0,82 düzeyinde olduğu, teknolojik duyarlılık boyutu açıklanan varyansın \%16'sını açıkladığı ve iç tutarlılık düzeyinin 0,82 düzeylerinde olduğu tespit edilmiştir. Toplam açıklanan varyansın \%84 olduğu ve genel olarak ölçeğin güvenilir olduğu belirlenmiştir.

Tablo 2: Alt Boyutların Karşılaştırılması

\begin{tabular}{|c|c|c|c|c|}
\hline Boyutlar & $\mathrm{x}$ & s.s. & $\mathrm{p}$ & Fark \\
\hline Çevresel Duyarlılık (1) & 4.33 & 0.59 & \multirow{5}{*}{0.01} & \multirow{5}{*}{$1>2,3,4,5$} \\
\hline Çevresel Katılım (2) & 4.06 & 0.58 & & \\
\hline Ekonomik Duyarlılık (3) & 4.05 & 0.63 & & \\
\hline Yeşil Satın alma (4) & 4.02 & 0.60 & & \\
\hline $\begin{array}{l}\text { Teknolojik } \\
\text { Duyarlılık (5) }\end{array}$ & 4.14 & 0.48 & & \\
\hline
\end{tabular}

Alt boyutlar arasında bir kıyaslama yapıldığında katılımcıların çevresel duyarlılık düzeylerinin çevresel katılım, ekonomik duyarlılık, yeşil satın alma ve teknolojik duyarlılık düzeylerine göre daha yüksek düzeylerde olduğu tespit edilmiştir $(p=0,01, p<0,05)$. Elde edilen bu sonuç Akbaba $(2019 ; 650)$ tarafindan yapılan turizm sektöründe 294 iş görene anket tekniği kullanılarak yapılan araştırma sonuçları ile örtüşmektedir. Yapılan bu araştırmada katılımcıların çevresel duyarlılık düzeyleri en yüksek seviyede olduğu tespit edilmiştir.

Genel olarak katılımcıların çevresel duyarlılık, çevresel katılım, ekonomik duyarlılık, yeşil satın alma ve teknolojik duyarlılık düzeylerinin oldukça yüksek düzeylerde olduğu, boyutların ortalama puanlarının 4 puan (5 puan üzerinden) üzerinde olduğu görülmüştür.

Tablo 3: Katılımcıların Özellikleri

\begin{tabular}{lcc}
\hline Cinsiyet & $\mathrm{n}$ & \% Yüzde \\
\hline Erkek & 78 & 75.7 \\
\hline Kadın & 25 & 24.3 \\
\hline $\begin{array}{l}\text { İşyerindeki } \\
\text { Konum }\end{array}$ & \\
\hline Müdür & 67 & 65.0 \\
\hline
\end{tabular}

\begin{tabular}{lll}
\hline Yardımcı & & \\
\hline Müdür & 36 & 35.0 \\
\hline Yaş & & \\
\hline $26-35$ & 20 & 19.4 \\
\hline $36-45$ & 44 & 42.7 \\
\hline 46 ve üzeri & 39 & 37.9 \\
\hline Hizmet Yılı & & \\
\hline $6-10$ yıl & 65 & 63.1 \\
\hline $11-15$ yıl & 14 & 13.6 \\
\hline 15yıl ve & 24 & 23.3 \\
üzeri & & \\
\hline Okul Tipi & & \\
\hline İlköğretim & 71 & 58.9 \\
\hline Lise & 15 & 14.6 \\
\hline Okul Öncesi & 17 & 16.5 \\
\hline
\end{tabular}

Katılımcıların \%76'sının erkek ve \%24'nün kadın, \%65'nin müdür yardımcısı ve \%35'nin müdür, \%19'nun 26-35 yaş, \%43'nün 36-45 yaş, \%38'nin 46 yaş ve üzerinde, \%63'nün 6-10 yıl arasında, \%14'nün 11-15 yıl arasında ve \%23'nün 15 yıl ve üzerinde çalışma yılına sahip olduğu tespit edilmiştir.

Tablo 4: Boyutlar ve Cinsiyet

\begin{tabular}{|c|c|c|c|c|c|}
\hline Boyutlar & Cinsiyet & $\mathrm{n}$ & $\mathrm{X}$ & s.s. & $\mathrm{p}$ \\
\hline \multirow[t]{2}{*}{ Çevresel Duyarlılık } & Erkek & 78 & 4.36 & 0.38 & \multirow[b]{2}{*}{0.42} \\
\hline & Kadın & 25 & 4.25 & 0.63 & \\
\hline \multirow[t]{2}{*}{ Çevresel Katılım } & Erkek & 78 & 4.08 & 0.58 & \multirow{2}{*}{0.43} \\
\hline & Kadın & 25 & 3.98 & 0.61 & \\
\hline \multirow[t]{2}{*}{ EkonomikDuyarlılık } & Erkek & 78 & 4.05 & 0.63 & \multirow{2}{*}{0.90} \\
\hline & Kadın & 25 & 4.06 & 0.63 & \\
\hline \multirow[t]{2}{*}{ Yeşil Satın alma } & Erkek & 78 & 4.03 & 0.60 & \multirow{3}{*}{0.74} \\
\hline & Kadın & 25 & 3.98 & 0.63 & \\
\hline Teknolojik & Erkek & 78 & 4.15 & 0.45 & \\
\hline Duyarlılık & Kadın & 25 & 4.10 & 0.55 & 0.63 \\
\hline
\end{tabular}

Katılımcıların cinsiyetlerine göre boyutlara karşılık duyarlılık düzeyleri incelendiğinde; kadın ve erkek katılımcıların çevresel duyarlılık, çevresel katılım, ekonomik duyarlılık, yeşil satın alma ve teknolojik duyarlılık düzeylerinin farklı olmadığı görülmüştür. Çevresel duyarlılık ( $\mathrm{p}=0,42 ; \mathrm{p}>0,05)$, çevresel katılım $(\mathrm{p}=0,43 ; \mathrm{p}>0,05)$, ekonomik duyarlılık $(0,90 ; \mathrm{p}>0,05)$, yeşil satınalma $(0,74 ; \mathrm{p}>0,05)$, teknolojik duyarlılı $(0,63$; p $>0,05)$. Elde edilen bu sonuç Özalp $(40 ; 2019)$ tarafindan yapılan araştırma sonuçları ile farklılık göstermektedir. Söz konusu araştırmada kadınların yeşil örgütsel davranış tutumlarının erkeklere oranla daha yüksek seviyede olduğu sonucu elde edilmiștir. Mevcut çalıșmada duyarlılık düzeylerinin aynı olması katılımcıların eğitim durumlarından kaynaklandığı ifade edilebilir. Aynı eğitim seviyesine sahip bireylerin çevresel duyarlılıklarının da birbirine yakın olabileceği sonucuna varılabilir.

Tablo 5: Boyutlar ve İşyerindeki Konum

\begin{tabular}{llllll}
\hline Boyutlar & $\begin{array}{l}\text { İşyerindeki } \\
\text { Konum }\end{array}$ & $\mathrm{n}$ & $\mathrm{X}$ & s.s. & $\mathrm{p}$ \\
\hline Çevresel Duyarlılık & $\begin{array}{l}\text { Müdür } \\
\text { yrd. }\end{array}$ & 67 & 4.34 & 0.55 & \multirow{2}{*}{0.85} \\
\cline { 2 - 5 } & Müdür & 36 & 4.32 & 0.67 & \\
\hline
\end{tabular}


Sönmez, R. V. / Anemon Muş Alparslan Üniversitesi Sosyal Bilimler Dergisi, 2020 8(4) 1107-1119

\begin{tabular}{|c|c|c|c|c|c|}
\hline \multirow[t]{2}{*}{ Çevresel Katılım } & $\begin{array}{l}\text { Müdür } \\
\text { yrd. }\end{array}$ & 67 & 4.03 & 0.58 & \multirow{3}{*}{0.69} \\
\hline & Müdür & 36 & 4.11 & 0.60 & \\
\hline \multirow[t]{2}{*}{ EkonomikDuyarlılık } & $\begin{array}{l}\text { Müdür } \\
\text { yrd. }\end{array}$ & 67 & 4.07 & 0.59 & \\
\hline & Müdür & 36 & 4.02 & 0.69 & \multirow{3}{*}{0.66} \\
\hline \multirow[t]{2}{*}{ Yeşil Satın alma } & $\begin{array}{l}\text { Müdür } \\
\text { yrd. }\end{array}$ & 67 & 4.04 & 0.56 & \\
\hline & Müdür & 36 & 3.98 & 0.69 & \\
\hline \multirow[t]{2}{*}{$\begin{array}{l}\text { Teknolojik } \\
\text { Duyarlılık }\end{array}$} & $\begin{array}{l}\text { Müdür } \\
\text { yrd. }\end{array}$ & 67 & 4.13 & 0.48 & \multirow[t]{2}{*}{0.80} \\
\hline & Müdür & 36 & 4.16 & 0.48 & \\
\hline
\end{tabular}

Katılımcıların iş yerindeki konumlarına göre çevresel duyarlılık, çevresel katılım, ekonomik duyarlılık, yeşil satın alma ve teknolojik duyarlılık düzeylerinin farklı düzeylerde olmadığı, okul müdürü veya müdür yardımcı olarak görev yapan katılımcıların çevresel duyarlılık, çevresel katılım, ekonomik duyarlılık, yeşil satın alma ve teknolojik duyarlılık düzeylerinin farklı olmadığı görülmüştür. Çevresel duyarlılık $(0,85 ; \mathrm{p}>0,05)$, çevresel katılım $(0,53$; $\mathrm{p}>0,05)$, ekonomik duyarlılı $(0,69 ; \quad \mathrm{p}>0,05)$, yeşil satınalma $(0,66 ; \mathrm{p}>0,05)$, teknolojik duyarlılık $(0,80$; $\mathrm{p}>0,05)$.

Tablo 6: Boyutlar ve Yaş

\begin{tabular}{|c|c|c|c|c|c|}
\hline Boyutlar & Yaş & $\mathrm{n}$ & $\mathrm{X}$ & s.s. & $p$ \\
\hline \multirow{4}{*}{$\begin{array}{l}\text { Çevresel } \\
\text { Duyarlılık }\end{array}$} & $26-35$ & 20 & 4.38 & 0.44 & \multirow{3}{*}{0.45} \\
\hline & $36-45$ & 44 & 4.39 & 0.35 & \\
\hline & 46 ve üzeri & 39 & 4.24 & 0.70 & \\
\hline & $26-35$ & 20 & 425 & 040 & \\
\hline \multirow[b]{2}{*}{$\begin{array}{l}\text { Çevresel } \\
\text { Katılım }\end{array}$} & $36-45$ & 44 & 4.07 & 0.56 & \multirow[t]{2}{*}{0.16} \\
\hline & 46 ve üzeri & 39 & 3.94 & 0.67 & \\
\hline \multirow{3}{*}{$\begin{array}{l}\text { Ekonomik } \\
\text { Duyarlılık }\end{array}$} & $26-35$ & 20 & 4.27 & 0.56 & \multirow{3}{*}{0.13} \\
\hline & $36-45$ & 44 & 4.06 & 0.60 & \\
\hline & 46 ve üzeri & 39 & 3.92 & 0.66 & \\
\hline \multirow{3}{*}{$\begin{array}{l}\text { Yeşil Satın } \\
\text { alma }\end{array}$} & $26-35$ & 20 & 4.25 & 0.44 & \multirow{3}{*}{0.10} \\
\hline & $36-45$ & 44 & 4.03 & 0.57 & \\
\hline & 46 ve üzeri & 39 & 3.89 & 0.68 & \\
\hline \multirow[b]{3}{*}{$\begin{array}{l}\text { Teknolojik } \\
\text { Duyarlılık }\end{array}$} & $26-35$ & 20 & 4.07 & 0.51 & \multirow{3}{*}{0.74} \\
\hline & $36-45$ & 44 & 4.16 & 0.45 & \\
\hline & 46 ve üzeri & 39 & 4.16 & 0.49 & \\
\hline
\end{tabular}

Katılımcıların yaşlarına göre çevresel duyarlılık, çevresel katılım, ekonomik duyarlılık, yeşil satın alma ve teknolojik duyarlılık düzeylerinin farklı düzeylerde olmadı̆̆ edilmiştir. Çalışmada 26-35 yaş, 36-45 yaş ve 46 yaş üzerinde olan katılımcıların çevresel duyarlılık, çevresel katılım, ekonomik duyarlılık, yeşil satın alma ve teknolojik duyarlılık düzeylerinin farklı olmadığı görülmüştür. Çevresel duyarlılık $(0,45 ; \mathrm{p}>0,05)$, çevresel katılım $(0,16$; $\mathrm{p}>0,05)$, ekonomik duyarlılı $(0,13 ; \quad \mathrm{p}>0,05)$, yeşil satınalma $(0,10 ; \mathrm{p}>0,05)$, teknolojik duyarlılık $(0,74$; p>0,05). Bu sonuç, Özalp'ın (41; 2019) yaptığı araştırma sonuçları ile örtüşmektedir. Söz konusu araştırmada yeşil örgütsel davranışın yaş değişkenine göre anlamlı bir fark olmadığı sonucunu elde etmiştir.

Tablo 7: Boyutlar ve Çalışma Yılı

\begin{tabular}{llllll}
\hline Boyutlar & Çalışma yılı & $\mathrm{n}$ & $\mathrm{X}$ & s.s. & $\mathrm{p}$ \\
\hline \multirow{3}{*}{ Çevresel } & $6-10$ & 65 & 4.35 & 0.56 & \\
\cline { 2 - 5 } & $11-15$ & 14 & 4.56 & 0.63 & 0.12 \\
\hline
\end{tabular}

\begin{tabular}{|c|c|c|c|c|c|}
\hline Duyarlilık & 15 yıl ve üzeri & 24 & 4.15 & 0.63 & \multirow{5}{*}{0.60} \\
\hline \multirow{3}{*}{$\begin{array}{l}\text { Çevresel } \\
\text { Katılım }\end{array}$} & $6-10$ & 65 & 4.07 & 0.56 & \\
\hline & $11-15$ & 14 & 4.14 & 0.61 & \\
\hline & 15 yıl ve üzeri & 24 & 3.96 & 0.65 & \\
\hline \multirow{3}{*}{$\begin{array}{l}\text { Ekonomik } \\
\text { Duyarl1l1k }\end{array}$} & $6-10$ & 65 & 4.07 & 0.63 & \\
\hline & $11-15$ & 14 & 3.91 & 0.57 & \multirow[t]{2}{*}{0.68} \\
\hline & 15 y1l ve üzeri & 24 & 4.07 & 0.67 & \\
\hline \multirow{3}{*}{$\begin{array}{l}\text { Yeşil Satın } \\
\text { alma }\end{array}$} & $6-10$ & 65 & 4.05 & 0.58 & \multirow{3}{*}{0.70} \\
\hline & $11-15$ & 14 & 3.90 & 0.60 & \\
\hline & 15 y1l ve üzeri & 24 & 4.01 & 0.67 & \\
\hline \multirow[b]{3}{*}{$\begin{array}{l}\text { Teknolojik } \\
\text { Duyarlılık }\end{array}$} & $6-10$ & 65 & 4.12 & 0.50 & \multirow{3}{*}{0.89} \\
\hline & $11-15$ & 14 & 4.19 & 0.42 & \\
\hline & 15 yıl ve üzeri & 24 & 4.15 & 0.45 & \\
\hline
\end{tabular}

Katılımcıların çalışma yıllarına göre çevresel duyarlılık, çevresel katılım, ekonomik duyarlılık, yeşil satın alma ve teknolojik duyarlılık düzeylerinin farklı düzeylerde olmadığı tespit edilmiştir. Çalışmada 6-10 yı1, 11-15 yıl ve 15 yıl üzerinde çalışma kıdemine sahip olan katılımcıların çevresel duyarlılık, çevresel katılım, ekonomik duyarlılık, yeşil satın alma ve teknolojik duyarlılık düzeylerinin farklı olmadığı görülmüştür.

Çevresel duyarlılık $(0,12 ; \mathrm{p}>0,05)$, çevresel katılım $(0,60$; $\mathrm{p}>0,05)$, ekonomik duyarlılı $(0,68 ; \mathrm{p}>0,05)$, yeşil satınalma $(0,70 ; p>0,05)$, teknolojik duyarlılık $(0,89$; $\mathrm{p}>0,05)$. Bu sonuç Özalp $(45 ; 2019)$ tarafindan yapılan araştırma sonuçları ile paralellik göstermektedir. Söz konusu çalışmada işgörenlerin yeşil örgütsel davranışlarının çalışma yıllarına göre farklılık göstermediği sonucu elde edilmiştir.

Tablo 8: Boyutlar ve Okul Tipi

\begin{tabular}{|c|c|c|c|c|c|}
\hline Boyutlar & Okul tipi & $\mathrm{n}$ & $\mathrm{X}$ & S.s. & $\mathrm{p}$ \\
\hline \multirow{3}{*}{ Çevresel Duyarlılık } & İlköğretim & 71 & 4.32 & 0.64 & \multirow{3}{*}{0.17} \\
\hline & Lise & 15 & 4.33 & 0.59 & \\
\hline & Okul öncesi & 17 & 4.37 & 0.37 & \\
\hline \multirow{3}{*}{ Çevresel Katılım } & İlköğretim & 71 & 4.09 & 0.61 & \multirow{3}{*}{0.66} \\
\hline & Lise & 15 & 3.91 & 0.63 & \\
\hline & Okul öncesi & 17 & 4.04 & 0.41 & \\
\hline \multirow{3}{*}{$\begin{array}{l}\text { Ekonomik } \\
\text { Duyarlılık }\end{array}$} & İlköğretim & 71 & 4.06 & 0.69 & \multirow{3}{*}{0.45} \\
\hline & Lise & 15 & 3.91 & 0.55 & \\
\hline & Okul öncesi & 17 & 4.15 & 0.36 & \\
\hline \multirow{3}{*}{ Yeşil Satın alma } & İlköğretim & 71 & 4.02 & 0.67 & \multirow{3}{*}{0.29} \\
\hline & Lise & 15 & 3.89 & 0.52 & \\
\hline & Okul öncesi & 17 & 4.12 & 0.27 & \\
\hline \multirow{3}{*}{$\begin{array}{l}\text { Teknolojik } \\
\text { Duyarlılık }\end{array}$} & İlköğretim & 71 & 4.12 & 0.52 & \multirow{3}{*}{0.81} \\
\hline & Lise & 15 & 4.27 & 0.39 & \\
\hline & Okul öncesi & 17 & 4.13 & 0.35 & \\
\hline
\end{tabular}

Katılımcıların görev yaptığı okul tiplerin göre çevresel duyarlılık, çevresel katılım, ekonomik duyarlılık, yeşil satın alma ve teknolojik duyarlılık düzeylerinin farklı düzeylerde olmadığı tespit edilmiştir. Çalışmada ilkokul, lise ve okul öncesi eğitim kurumlarında çalışan katılımcıların çevresel duyarlılık, çevresel katılım, ekonomik duyarlılık, yeşil satın alma ve teknolojik duyarlılık düzeylerinin farklı olmadığ görülmüştür. Çevresel duyarlılık $(0,17 ; \mathrm{p}>0,05)$, çevresel katılım $(0,66 ; \mathrm{p}>0,05)$, ekonomik duyarlılık $(0,45 ; \mathrm{p}>0,05)$, yeşil satınalma $(0,29 ; p>0,05)$, teknolojik duyarlılık $(0,81$; $\mathrm{p}>0,05)$. 
Tablo 9: Yeşil Örgütsel Davranış Ölçeği Alt Boyutlarının İncelenmesi

\begin{tabular}{lll} 
Çevresel & $\mathrm{r} \quad 1$ \\
\cline { 2 - 2 } Duyarlılık & $\mathrm{p}$
\end{tabular}

\begin{tabular}{lll} 
Çevresel- & $\mathrm{r} 0.533^{* *} 1$ \\
\cline { 2 - 3 } Kat1lım & $\mathrm{p} 0.01$
\end{tabular}

\begin{tabular}{|c|c|c|c|c|c|}
\hline \multirow{2}{*}{$\begin{array}{l}\text { Ekonomik } \\
\text { Duyarlılık }\end{array}$} & r $0.301 * *$ & $0.609 * *$ & \multicolumn{3}{|l|}{1} \\
\hline & p 0.01 & 0.01 & & & \\
\hline \multirow{2}{*}{$\begin{array}{l}\text { Yeşil- } \\
\text { Satınalma }\end{array}$} & r $0.447 * *$ & $0.573 * *$ & $0.888 * *$ & 1 & \\
\hline & p 0.01 & 0.01 & 0.01 & & \\
\hline \multirow{2}{*}{$\begin{array}{l}\text { Teknolojik- } \\
\text { Duyarlılık }\end{array}$} & r 0.14 & -0.04 & -0.39 & -0.35 & 1 \\
\hline & P 0.16 & 0.69 & 0.01 & 0.01 & \\
\hline
\end{tabular}

Katılımcıların çevresel duyarlılık düzeyleri ile çevresel katılım düzeyleri arasında pozitif, orta düzeyde ve anlamlı ilişki olduğu görülmüştür $(r=0,533, p=0,01)$.

Katılımcıların çevresel duyarlılık düzeyleri ile ekonomik duyarlılık düzeyleri arasında pozitif, zayıf düzeyde ve anlamlı ilişki olduğu görülmüştür $(r=0,301, p=0,01)$.

Katılımcıların çevresel duyarlılık düzeyleri ile yeşil satın alma düzeyleri arasında pozitif, orta düzeyde ve anlamlı ilişki olduğu görülmüştür $(r=0,447, p=0,01)$.

Katılımcıların çevresel duyarlılık ve teknolojik duyarlılık düzeyleri arasında anlamlı ilişki olmadığı tespit edilmiştir $(\mathrm{p}>0,05)$.

Katılımcıların çevresel katılım ve ekonomik duyarlılık düzeyleri arasında pozitif, güçlü düzeyde ve anlamlı ilişki olduğu görülmüştür $(r=0,609, p=0,01)$.

Katılımcıların çevresel katılım ve yeşil satın alma düzeyleri arasında pozitif, orta düzeyde ve anlamlı ilişki olduğu görülmüştür $(r=0,573, p=0,01)$.

Katılımcıların çevresel katılım ve teknolojik duyarlılık düzeyleri arasında anlamlı ilişki olmadı̆̆ı tespit edilmiştir( $(\mathrm{p}>0,05)$.

\section{Sonuç ve Öneriler}

Yaşadığımız yüzyılda teknoloji, makineleşme, iletişim, ulaşım ve üretim alanında yaşanana hızlı gelişme ve ilerleme insanoğlunun hayatını kolaylaştırmakta, konforunu artırmakta ve ihtiyaçların giderilmesi konusunda değişik alternatifler sunmaktadır. Teknolojinin hızı her geçen gün artmakta, bugün yeni olan bir ürün kısa süre sonra eskiyebilmektedir. Teknoloji, üretim ve hizmet alanında yaşanan bu gelişmeler daha fazla kaynak kullanımını gerektirmektedir. Kullanılan bu kaynakların önemli bir kısmının doğal çevreden elde edildiği, doğal çevrede sınırlı miktarda bulunan bu kaynakların hızla tüketildiği bir gerçektir. Diğer taraftan örgütler bu kaynakları kullanmakla yetinmeyip, faaliyetleri sonrası oluşan atıkları da doğal çevreye salmakta, dolayısıyla doğal çevreye zarar vermektedir. Sonuç olarak ekolojik dengeyi bozabilmektedir.

Doğal çevrenin ve ekolojik dengenin bozulması sonucu oluşan sorunlar ve bunlara yönelik çözüm yolları son dönemlerde insanoğlunun gündemine oturmuş, araştırmacılar konu ile ilgili çalışmalarına hız vermiş, kamu yöneticileri de çevrenin korunması ile ilgili yasal düzenlemeleri yürürlüğe geçirmiştir. Kamu sektöründe çalışan yöneticilerde yürürlüğe konulan bu yasal düzenlemelerle birlikte hizmet verdikleri kitlenin de beklentilerini dikkate alarak kamu kaynaklarını etkin, verimli ve tasarruflu kullanmak, kaynakları kullanırken doğal çevreyi dikkate almak durumunda kalmışlardır. Bu yeni süreç kamu ve özel sektör yöneticilerini işletme kaynaklarını daha tasarruflu kullanmaya, çevreye karşı daha duyarlı olmaya, doğal çevrenin korunması için daha çok çaba sarf etmeye zorlamıştır.

Kamu sektöründe hizmet veren ve ülkenin hemen hemen her yerleşim bölgesinde bulunan kurumlardan biri de Millî Eğitim Bakanlığına bağlı örgün eğitim kurumlarıdır. Bu çalışmanın amacı; eğitim işletmelerinde faaliyette bulunan yöneticilerin yeşil örgütsel davranışlarını belirlemek, bir başka ifade ile okul yöneticilerinin çevresel duyarlılık, çevresel katılım, ekonomik duyarlılık, yeşil satın alma ve teknolojik duyarlılık düzeylerini ölçmek, bu konudaki tutumlarını belirlemek, ilgili literatüre katkı sunmak, konu ile ilgili bir tartışma ortamı yaratabilmektir.

Araştırma sonucunda elde edilen sonuçlardan biri; alt boyutlar arasında bir kıyaslama yapıldığında katılımcıların çevresel duyarlılık düzeylerinin çevresel katılım, ekonomik duyarlılık, yeşil satın alma ve teknolojik duyarlılık düzeylerine göre daha yüksek seviyede olduğu tespit edilmiştir $(p=0,01, p<0,05)$. Bu sonuç Akbaba $(2019 ; 642)$ tarafından yapılan çalışma ile paralellik göstermektedir. Söz konusu çalışma da katılımcıların en fazla çevresel duyarlılık boyutuna duyarlı oldukları sonucu elde edilmiştir.

Genel olarak katılımcıların çevresel duyarlılık, çevresel katılım, ekonomik duyarlılık, yeşil satın alma ve teknolojik duyarlılık düzeylerinin oldukça yüksek düzeylerde olduğu, boyutların ortalama puanlarının 4 puan ( 5 puan üzerinden) üzerinde olduğu görülmüştür. $\mathrm{Bu}$ sonucun ortaya çıkmasında okul yöneticilerinin her birinin en az lisans mezunu olmalarından, çevre tahribatı ve ekolojik dengenin öneminden haberdar olmalarından kaynaklandığı ifade edilebilir. Eğitim seviyesi arttıkça bireylerin çevreye karşı duyarlılığı, ekolojik dengenin korunması, doğal kaynaklara ve kaynakların kullanımında verimliliğe ve tasarrufa önem verdiği, okul yöneticilerinin faaliyetleri sonucu oluşan atıklarında doğal çevreye en az zararla salınması konusunda duyarlı oldukları sonucuna ulaşılabilir. Elde edilen bu veriden yola çıkarak doğal çevrenin korunması ve doğal kaynakların tasarruflu ve verimli kullanımı konusunda duyarlı ve bilinçli bir toplum ve iş görenler için önemli bir hususun bireylerin eğitimi olduğunu ifade edebiliriz. Doğal çevrenin ve doğal kaynakların korunması ve gelecek nesillerin ihtiyaç duyacağı bir doğal çevreyi miras olarak bırakma konusunda verilecek eğitimlerin, okul yöneticilerinin bilinç düzeyini artırabileceği, kullandıkları kaynakları çevresel duyarlılık, ekonomik duyarlılık, çevresel katılım, yeşil satınalma ve teknolojik duyarlılık ilkelerine uygun bir şekilde kullanacakları sonucuna varılabilir. Eğitim seviyesinin artırılması ile doğal çevre ve 
doğal kaynakların önemi konusunda okul yöneticilerinin daha fazla bilgi sahibi olabileceği, kaynakların tükenmesi ve ekolojik dengenin bozulması sonucunda insanoğlunun karşılaşabileceği tehlikelerin farkına varma noktasında daha duyarlı bir seviyede olabilecekleri sonucuna varılabilmektedir. Okul yöneticilerinin doğal çevreye ve kaynaklara karşı, çevresel duyarlılık, çevresel katılım, ekonomik duyarlılık, yeşil satın alma ve teknolojik duyarlılık düzeylerini artırmak ve farkındalıklarını artırmak için konu ile ilgili eğitim seviyelerinin artırılması önerilebilir. Bu sonuç, Yiğit $(2017 ; 69)$ tarafından yapılan çalışma ile örtüşmektedir. Yapılan çalışmada iş görenlerin çevresel duyarlılıklarının artması ve konu ile ilgili farkındalıklarının oluşturulması için yöneticilerin yol göstermesi ve iş görenlerini bu konuda eğitmeleri sonucu elde edilmiştir. Bununla birlikte Ones ve Dilchert (2012: 444-466) yaptıkları çalışma sonucunda, örgütlerin sürdürülebilir bir çevreye katkı sağlamalarının önemli aşamalarından birinin iş görenlere rehberlik yapılması ve yönlendirilmeleri gerektiği sonucunu elde etmişlerdir.

Araştırma sonucunda elde edilen bir diğer sonuç; okul yöneticilerinin çevresel duyarlılık düzeyleri ile çevresel katılım düzeyleri arasında pozitif, orta düzeyde ve anlamlı ilişki olduğu görülmüştür $(r=0,533, p=0,01)$. Çevresel duyarlılık davranışı, iş yerinde kullanılan enerjinin gereksiz yere kullanılmasını engellemeyi, enerji kaynaklarının fazla kullanılmasına yol açan malzemelerin değiştirilmesi veya kullanımdan çıkarılmasını, geri dönüşüme kazandırılma imkânı olan malzemelerin muhafaza edilmesi ve ilgili yerlere gönderilmesini, atık malzemelerin kullanılması ve değerlendirilmesini, su ve elektrik kaynaklarının tasarruflu kullanımını ifade eder. Çevresel duyarlılık davranışını gösteren yöneticiler, bu davranışlarını doğal çevreyi koruma istek ve çabaları, doğal çevreye duyarlı olan örgütleri tercih etmeleri, örgüt çatısı altında çalışan iş görenlere doğal çevreye zarar verecek davranışlarda bulunulmasını engellemeye çalışmak istemektedirler. Bununla birlikte yöneticilere, ortaklara ve diğer paydaşlara çevrenin korunması konusunda öneriler sunmaları, çevrenin korunmasına yönelik faaliyetlere katılım sağlamaları, örgüt yönetimi ve kamu yönetimi tarafindan konulan yasal uygulamalara uyma çabaları şeklinde devam ettirmeleri bu sonucun ortaya çıkmasında etkili olabileceği ifade edilebilir. Bir başka ifade ile çevresel duyarlılık boyutu işletmenin iç yapısı ile ilgili hassasiyeti, çevresel katılım bu hassasiyetin devamı ve korunması ile ilgili faaliyetleri kapsadığ 1 ifade edilebilir. Bu nedenle örgüt yöneticilerinin bu konuda iş görenlere yol göstermeleri ve örnek davranışlar sergilemeleri, özellikle çevre ile ilgili yasal mevzuata uygun davranış sergilemeleri diğer iş görenlere de örnek teşkil edebilecek, çevresel duyarlılık ve çevresel katılım davranışlarının iş görenler arasında yaygınlık kazanmasına katkı sunabilecektir.

Araştırmanın sonuçlarından biri de katılımcıların çevresel duyarlılık düzeyleri ile ekonomik duyarlılık düzeyleri arasında pozitif, zayıf düzeyde ve anlamlı ilişki olduğudur $(\mathrm{r}=0,301, \quad \mathrm{p}=0,01)$. İş ortamında gün 1şı̆̆ından yararlanmayı, eldeki kaynaklardan tam kapasite ile faydalanmayı, kullanılan enerji kaynakları ile ilgili ortaya çıkabilecek kayıpların en aza indirilmesi için gerekli tedbirlerin alınması, ulaşım sürecinde toplu taşıma araçlarının tercih edilmesini ifade eden ekonomik duyarlılık davranışını gösteren yöneticilerin bununla birlikte örgüt çatısı altında kullanılan başta enerji kaynakları olmak üzere tüm kaynakların verimli ve etkin kullanımını da sağlamak istemeleri ve bu yönde çaba harcamaları bu sonucun ortaya çıkmasında etkili olabileceği sonucuna varılabilir. Ekonomik duyarlılık ve çevresel duyarlılık kavramları örgütler için önem arz eden maliyet kavramını da etkileyebilmektedir. Bu nedenle örgüt ortamında ekonomik duyarlılık ve çevresel duyarlılık davranışlarının örgüt kültürünün bir parçası haline getirilmesi ve bu davranışların teşvik edilip gerekirse ödüllendirilmesi önem kazanmaktadır.

Katılımcıların Çevresel duyarlılık düzeyleri ile yeşil satın alma düzeyleri arasında pozitif, orta düzeyde ve anlamlı ilişki olduğu görülmüştür $(r=0,447, p=0,01)$. Örgütsel çatı altında çalışan işgörenlerin her türlü kaynakların tasarruflu kullanılması ve doğal çevreye en az derecede zarar verecek şekilde kullanımına özen göstermeleri, bu düşünce ve davranışlarını ihtiyaçlarını giderme amacıyla ürün satın alırken de göstermeleri, bir başka ifade ile işgörenlerin çevreye karşı duyarlı olma davranışlarını ürün satın alırken çevreye duyarlı, doğaya en az zarar veren ürünleri tercih etmeleri bu sonucun ortaya çıkmasında etkili olduğunu ifade edebiliriz. Bu sonuç Zainudun ve arkadaşları (2013; 866) tarafından yapılan araştırma sonuçları ile paralellik arz etmektedir. Söz konusu araştırma sonucunda; bireylerin yeşil ürünleri satınalma ve tüketmelerinde çevre konusunda sahip olunan bilginin önemli bir etken olduğu verisi elde edilmiştir.

Katılımcıların çevresel katılım ve ekonomik duyarlılık düzeyleri arasında pozitif, güçlü düzeyde ve anlamlı ilişki olduğu görülmüştür $(\mathrm{r}=0,609, \mathrm{p}=0,01)$. Okul yöneticilerinin doğal çevreye zarar verecek davranışlardan kaçınması ve çevrenin korunması faaliyetlerine katılım sağlaması ve bu düşünce ve davranışlarını mevcut kaynakları kullanırken devam ettirmeleri, özellikle enerji kaynaklarını tasarruflu kullanma çabası bu sonucun ortaya çıkmasında etkili olduğu sonucuna ulaşılabilir. Buna göre okul yöneticilerinin seçimi ve atamasında istenilen birtakım özelliklerle birlikte çevresel katılım ve ekonomik duyarlılıklarını da dikkate almak önem arz etmektedir.

Katılımcıların çevresel katılım ve yeşil satın alma düzeyleri arasında pozitif, orta düzeyde ve anlamlı ilişki olduğu görülmüştür $(\mathrm{r}=0,573, \quad \mathrm{p}=0,01)$. Katılımcıların başta çevrenin korunması ile ilgili yasal düzenlemelere uyma olmak üzere, çevreye zarar verecek davranışlardan kaçınma çabaları ve doğal çevreye duyarlı olan örgütlerin seçilmesi ile ilgili davranış ve faaliyetlerini, ekonomik faaliyetleri sürecinde devam ettirmek istemeleri, çevreye duyarlı örgütlerin ürünlerini tercih etmeleri, tüketim sonrası çevreyi koruyan örgütlerin ürünlerini satın alma davranışı göstermeleri bu sonucun ortaya çıkmasında etkili olduğu ifade edilebilir. $\mathrm{Bu}$ sonuç Mostafa $(2007$; 445) tarafindan yapılan araştırma sonuçları ile örtüşmektedir. Yapılan bu çalışmada tüketicilerin yeşil satınalma davranışı ile doğal çevreyi koruma davranışı arasında anlamlı bir ilişki olduğu sonucu elde edilmiştir.

Bu sonuca göre örgütler eğitim camiasının büyüklüğünü de dikkate alarak özellikle okul yöneticilerinin faaliyetlerini icra ederken kullandıkları ürünlerin çevreye vereceği zararı dikkate almaları ve doğal çevre ile uyum sağlayan ürün üretmeleri gerekmektedir 
Son dönemlerde insanoğlunun gündemindeki maddelerin ilk sıralarında yer alan daha yaşanabilir bir dünya ve daha temiz çevre fikri, doğal çevrenin korunması ve kaynaklarının dikkatli kullanılmasını önemli hale getirmiştir. Ancak bu fikrin hayat bulması ve gerçekleşebilmesi için yaşadığımız süreç içinde sadece bireylerin değil aynı zamanda kamu ve özel sektörde faaliyette bulunan örgütlerin de doğal çevrenini korunması konusunda daha dikkatli ve özenli olmaları gerektiği bir gerçektir. Yaşadığımız yüzyılda yaşanana iklim değişikleri, doğal afetler ve çevre kirlenmesinin başlıca sebeplerinden biri örgütlerin doğal kaynak kullanımında görülen artıştır. Daha yaşanabilir bir dünya ve daha temiz çevre için sadece örgütler değil aynı zamanda örgüt çatısı altında çalışan iş görenlerinde doğal çevre ve doğal kaynakların kullanımı konusunda duyarlı olmaları ve doğal çevreyi koruyacak davranışları göstermeleri, kullanılan kaynakların tasarruflu kullanımına özen göstermeleri gerekmektedir.

Elde edilen tüm veriler ışı̆̆ında aşağıdaki öneriler geliştirilebilir.

(i) Okul yöneticilerinin doğal çevreyi koruma ve kaynakları tasarruflu kullanma konusunda duyarlılıklarını ve becerilerini geliştirmek amacıyla eğitilmesini kamu yöneticileri bir politika haline getirmelidirler.

Belirli bir eğitim almış, çevre, iklim, ekolojik denge ve doğal kaynakların sınırlı olduğu konularında bilgi sahibi olan okul yöneticilerinin işyerinde kullandıkları kaynakları daha bilinçli ve tasarruflu kullanacağı bir gerçektir. Bu nedenle çevresel duyarlılık, çevresel katılım, teknolojik ve ekonomik duyarlılık konularında okul yöneticilerinin duyarlılıklarını artırmak amaciyla temel eğitim ve yükseköğretim safhalarında çevre bilincini geliştirecek müfredatlara yer verilmelidir.

(ii) Özellikle örgütsel kaynakların tasarruflu bir şekilde kullanımını sağlamak amacıyla hizmet içi eğitim programlarının uygulanması okul yöneticilerinin ekonomik duyarlılıkların artırabilecektir.

(iii) Doğal çevreye karşı duyarlı olmak ve doğal çevreye zarar vermemek okul yöneticilerini aynı sahada faaliyet gösteren diğer yöneticilerden farklı kılacaktır. Bu farklılık hizmet verilen hedef kitle nezdinde de olumlu bir kurumsal imajin oluşmasına katkı sağlayabilecektir. Okul yöneticileri birlikte çalıştığ 1 iş görenlerin de çevresel duyarlılığını artırmak için rol model olmalıdırlar.

(iv) Okul yöneticileri eğitim hizmeti sürecinde ve sonrasında doğal kaynakları tasarruflu kullanmak ve hizmet sonrası doğal çevreyi korumak veya en az zararı vermek, bu uygulamaları eğitim örgütünün bir politikası haline getirmeleri gerekmektedir.

(v) Yeşil örgütsel davranış konusunda okul yöneticilerinin özen göstermeleri gereken bir diğer husus hizmet sonrası ortaya çıkan atıkların zararsız hale getirilmesi veya geri dönüşüm yolu ile tekrar kullanıma kazandırılması amacıyla çalışmalar yürütmeleridir. Hizmet sonrası ortaya çıkan atıkların tekrar kullanıma kazandırılması bir taraftan doğal kaynakların tüketim oranını düşürmekte, diğer taraftan okul kaynaklarının da tekrar kullanılarak tasarruf sağlanabilmektedir. Bu konuda özellikle okul ortamında oluşan atıkların ayrıştırılması ve bu şekilde ilgili yerlere sevk edilmesi önemlidir.

(vi) Yeşil örgütsel davranışın örgüt içinde yaygınlaşması ve iş görenler nezdinde kabul görebilmesi için, okul yöneticilerin bu konuda bir örgüt kültürü oluşturmaları, yeşil işletme strateji ve uygulamalarını işletmenin bir felsefesi haline getirmeleri gerekmektedir.

(vii) Okulların kuruluş yerinin seçimi, çevreye zarar vermeyecek şekilde tasarımı ve inşası da okul yöneticilerinin doğal çevrenin korunması açısından başvurabilecekleri bir diğer yöntemdir. Eğitim kurumunun kuruluş yerinin doğal çevreye zarar vermeyecek bölgelerde seçimi, özellikle doğal çevre ve kaynakları (hava kalitesi, su kaynakları) kirletmeyecek şekilde tasarımı atılacak önemli adımlardan biri olabilir.

(viii) Okul yöneticilerinin doğal kaynaklar ve çevrenin korunması ile ilgili atacakları önemli adımlardan biri de yenilenebilir enerji kaynaklarının (rüzgâr, su, güneş) kullanımıdır. Yenilenebilir enerji kaynak kullanımı bir taraftan çevreye minimum düzeyde zarar verirken diğer taraftan okul maliyetlerinde bir avantaj yaratabilecektir.

(ix) Enerji tasarrufunun sağlanması için gün 1şı̆̆ından mümkün mertebe fazla yararlanılmalı. Gerekirse çalışma saatleri buna uygun hale getirilmelidir.

(x) Ekonomik duyarlılık, çevresel duyarlılık, çevresel katılım ve yeşil satınalma davranışları okul kültürünün bir parçası haline getirilmelidir.

(xi) Eğitim hizmeti yerine getirilirken tasarruflu araç ve malzemelerin kullanımı özendirilmelidir. Atık malzemelerin dönüşüm yolu ile kazandırılmasına dikkat edilmelidir.

(xii) Okul yöneticilerinin seçimi ve atamasında kaynakların tasarruflu kullanımı ve çevresel katılım duyarlılığı konularında eğitim almış veya faaliyetlerde bulunmuş olan adaylara pozitif ayrımcılık yapılmalıdır.

(xiii) Okul ortamında gereksiz kullanılan enerjinin önüne geçilmelidir.

(xiv) Eğitim hizmeti için ihtiyaç duyulan malzemelerin alınmasında yeşil satınalma davranışı sergilenmelidir.

(xv) Yöneticiler tarafindan yapılan iş tanımlarında yeşil örgütsel davranış tanımlarına da yer verilmesi, okul çalışanlarının bu konuda daha duyarlı olmalarını sağlayabilecektir.

(xvi) Doğal çevrenin korunması için çıkarılan hukuki düzenlemelere uyum sağlanmalıdır.

(xvii) Okul yöneticileri doğal çevreye karşı sosyal sorumluluk bilinciyle hareket etmeleri gerekmektedir. 
(xviii)

Okul yöneticileri karar alma süreçlerinde doğal çevreyi dikkate almaları gerekmektedir. Güncel olarak değerlendirildiğinde yeşil örgütsel davranış konusunda gerek kamu gerekse özel sektör iş görenlerinin istenilen düzeyde duyarlılık göstermediği düşünülmektedir. $\mathrm{Bu}$ nedenle yöneticiler işgörenlerin de çevresel duyarlılıklarını artırmak için programlar düzenlemelidir.

Araştırmacılar imalat, hizmet, sağlık ve turizm gibi farklı sektörlerde özellikle sanayi sektöründe faaliyet gösteren işletmelerde konu ile ilgili daha büyük evrende karşılaştırmalı araştırmalar yaparak, sektörlerin bu konudaki eğilimlerini belirleyip, daha temiz ve daha sürdürülebilir bir çevre için çözüm yolları belirlemelidir. Diğer taraftan araştırma sadece bir merkezdeki resmi okullarda yapılmıştır. Ülkede bulunan tüm okullar araştırmalara dahil edilerek genişletilebilir.

Araştırma maliyet ve zaman kısıtlılığından dolayı sadece Şırnak ili Cizre İlçesinde resmi okullarda görev yapan okul yöneticilerini kapsamaktadır. İlgili alan yazında erişime açık kaynakların ve araştırmaların az olması bir diğer kisitlayıcı unsurdur.

\section{Kaynakça}

Akbaba, M. (2019) Örgütsel Adalet İşgörenlerin Yeşil Ör gütsel Davranışını Etkiler mi? Trakya Üniversitesi Sosyal Bilimler Dergisi Aralık 2019 Cilt 21 Sayı 2 (641-660)

Aydın, E. (2012). Orhon Yazıtları (Köl Tigin, Bilge Kağan, Tonyukuk, Ongi, Küli Çor). Konya: Kömen Yayınları.Bayraktutan, Y., İnmez İ. (2017) Çevre Sorunları, Uluslararası Ticaret ve Kuruluş Yeri Tercihleri, Uluslararası Ekonomik Araştırmalar Dergisi, Eylül 2017, Cilt:3, Say1:3.

Dünya Sağlık Örgütü https://www.who.int/; (08.08.2019)

Erbaş1, A. (2018) Yeşil Örgütsel Davranış: Özgün Bir Ölçek Geliştirme, 6. Örgütsel Davranış Kongresi Bildiriler Kitabı 2-3 Kasım 2018 / Isparta

Erbaşı, A. (2019). Yeşil Örgütsel Davranış Ölçeği: Bir Ölçek Geliştirme Çalışması. Istanbul Management Journal, (86), 1-23. Retrieved from

Eriçok, B., (2014) Eğitim Yönetimi Teftişi Planlaması Ve Ekonomisi Yüksek Lisans Programı Okul Yöneticilerinin Duygusal Zekâ Düzeyleri İle Yönetsel Yeterlik Düzeyleri Arasındaki İlișki. Yayımlanmamış Yüksek Lisans Tezi. Eğitim Bilimleri Enstitüsü Eğitim Bilimleri Anabilim Dalı. Tokat: Gaziosmanpaşa Üniversitesi, 2014.

Gökbunar, A., R., (1995), İşletmelerin Çevrenin Korunmasinda Sosyal Sorumluluğu, Ekoloji Çevre Dergisi, 1995, S:14, syf.5

Görmez, K. (1997): Çevre Sorunları ve Türkiye, Gazi Kitabevi Yayınları:45, Ankara, 2. Bask1.

Haden, S. S. P., Oyler, J. D., \& Humphreys, J. H. (2009). Historical, Practical, and Theoretical Perspectives on Green Management: An Exploratory Analysis.
Management Decision, 47(7), 1041-1055. https://doi.org/10.1108/00251740910978287

Hart, S.L. (2008). "Yeşilleşmenin Ötesi: Sürdürülebilir Bir Dünya İçin Stratejiler”, Yeşil İş Stratejisi (çev: Ahmet Kardam), Harvard Business Review Dergisinden Seçmeler, Mess Yayımcılık, 2008, İstanbul.

Kahraman, N., \& Türkay, O. (2014). Turizm ve çevre. Detay Yayıncılık.

Karakuş, G., ve Erdirençelebi. M. (2018). İșletmelerin Yeşil Yönetim Algılarının İşletme Performansı Üzerindeki Etkisini Ölçmeye Yönelik Bir Araştırma, İşletme Araştırmaları Dergisi Journal of Business ResearchTurk 10/4 (2018) 681-704

Keleş, R. ve Hamamcı, C. (2005) Çevre Politikası, İmge Kitabevi, Ankara.

Kim, A., Kim, Y., Han, K., Jackson, S., \& Ployhart, R. E. (2014). Multilevel influences on voluntary workplace green behavior: individual differences, leader behavior, and coworker advocacy. Journal of Management. doi: $10.1177 / 0149206314547386$.

Koçarslan, H. (2015) İşletmelerin Sosyal Sorumluluk Bilincinde Çevre Duyarlılığının Yeşil Pazarlama Üzerine Etkileri, Kilis 7 Aralık Üniversitesi Sosyal Bilimler Enstitüsü

Lee, J. J., Gemba, K., Kodama, F. (2006). Analyzing the innovation process for environmental performance improvement. Technological Forecasting and Social Change, 73(3), 290-301.

Mesmer-Magnus, J., Viswesvaran, C., and Wiernik, B.M. (2012). The Role of Commitment in Bridging The Gap Between Organizational Sustainability and Environmental Sustainability. In S. E. Jackson, D.S. Ones, and S. Dilchert (Eds.), Managing HR for environmental sustainability,155-186. San Francisco, Jossey-Bass/Wiley.

Milli Eğitim Bakanlığı, http://sgb.meb.gov.tr/www/icerik_goruntule.php?KNO= $361(05.02 .2020)$.

Mishra, P., Sharma, P. (2010), "Green Marketing in India: Emerging Opportunities and Challenges", Journal of Science and Management Education, Volume.3, (9-14).

Molina-Azorin, J. F., Claver-Cortes, E., Lopez-Gamero, M. D. ve Tari, J. J. (2009). Green Management and Financial Performance: a Literature Review. Management Decision, 47(7),1080-1100. https://doi.org/10.1108/00251740910978313.

Mostafa, M.M., (2007). "A hierarchical analysis of the green consciousness of the Egyptian consumer", Psychology and Marketing, Vol.24, No.5, 445-473.

Ones, D.S., and Dilchert, S. (2012). Environmental Sustainability at Work: A Call to Action. Industrial and Organizational Psychology: Perspectives on Science and Practice, 5, 444-466.

Özalp, Ö. (2019) Otel Çalışanlarının Yeşil Örgüt İklimi Algılarının Yeşil Örgütsel Davranışları Üzerine Etkisi, Selçuk üniversitesi Sosyal Bilimler Enstitüsü Turizm 
İşletmeciliği Anabilim Dalı Turizm İşletmeciliği Bilim Dalı, Yayınlanmamış Y. Lisans Tezi

Ritter, Agata M., Borchardt, M., Vaccaro, Guilherme L.R., Pereira, Giancarlo M., Almeida, F. (2015), "Motivations for promoting the consumption of green products in an emerging country: exploring attitudes of Brazilian consumers", Journal of Cleaner Production, Volume.106, (507-520).

Shrivastava, P. (1995). "Ecocentric Management For A Risk Society", Academy of Management Review, 20/1, 118-137

Siegel, D. S. (2009). Green Management Matters Only If It Yields More Green: An Economic/Strategic Perspective. Academy of Management Perspectives, 23(3), $5-\quad 16$. https://doi.org/10.5465/AMP.2009.43479260

Simula, H., Lehtimaki, T., \& Salo, J. (2009). Managing Greenness in Technology Marketing. Journal of Systems and Information Technology, 11(4), 331-346. https://doi.org/10.1108/13287260911002486

Stern, P.C. (2000). Toward a Coherent Theory of Environmentally Significant Behavior. Journal of Social Issues, 56 (3), 407-424.

Straughan, R., James A. R. (1999), "Environmental Segmentation Alternatives: A Look at Green Consumer Behavior in The New Millennium", Journal of Consumer Marketing, Vol.16, N.6:558-575.

Sürdürülebilir kalkınma Dünya zirvesi Türkiye ulusal raporu www.resmigazete.gov.tr . (06.11.2019).

Sürdürülebilir Kalkınma Türkiye Ulusal Raporu (2002): Birleşmiş Milletler Kalkınma Programı ile T.C. Çevre Bakanlığı Ortak Projesi, İş Dünyası ve Sanayi, Sürdürülebilir Kalkınma Dünya Zirvesi, baskı: MAS AŞ, 1. basım: Aralık, 2002, Ankara.
Tekin, T. (1968). A Grammar Of Orkhon Turkic. Bloomington: Indiana University

Tıraş, H., (2002). Sürdürülebilir Kalkınma ve Çevre: Teorik Bir İnceleme K.S.İ. Üniv. İ.İ.B.F. Dergisi, Cilt:2, Say1:2,2002, S.57-73.

Torunoğlu, E., Koparal, A. S., Tezcan, Ü., Göncü, S. (2013). Çevre Sorunları ve Politikaları. Eskişehir: Anadolu Üniversitesi Yayınları

Ünal, S., Sefer A. (2001) Öğretmenlik Mesleğine Giriş. İkinci basım. İstanbul: Marmara Üniversitesi Döner Sermaye İşletmesi Teknik Eğitim Fakültesi Matbaa Birimi, 2001.

Varinli, İ. (2000). Pazarlama Ahlakı ve Kayseri'de Küçük ve Orta Ölçekli İşletme Yöneticilerinin Pazarlama Ahlakına İlişkin Değerlendirmeleri, Kayseri Ticaret Odası Yayınları, Yayın No:15.

www.meb.gov.tr. Millî Eğitim Bakanlığı Eğitim Kurumları Yöneticileri Atama ve Yer Değiştirme Yönetmeliği, (18.09.2019)

Yılmaz, K. (2006). Örgütlerin Sosyal Sorumlulukları: Kavramsal Bir Çözümleme, Mehmet Akif Ersoy Üniversitesi Eğitim Fakültesi Dergisi, .65-79. (http://efd.mehmetakif.edu.tr/arsiv/Aralik2006/sayi12/ 65-79.pdf). [15.08.2019].

Yiğit, B. (2017) Örgütsel Davranışta Yeni Bir Yaklaşım: Yeşil İş gören Davranışı, Uluslararası Beşerî ve Sosyal Bilimler Dergisi, Volume: I Issue:1, 67-70.

Zainudin, A., Saripah, A.L., Mohd Shukri, O., Yeop Hussin, B., (2013). "From research to practice: role of environmen tal knowledge in creating proenvironmental residents", Asia Pacific International Conference on Environment-Behavior Studies, University of Westminster, London, 4-6 September, Procedia-Social and Behavioral Sciences 105, 866-874, online: $\quad$ www.sciencedirect.com. 